\title{
ANALISIS PERENCANAN PUTARAN BALIK (U-TRUN) STUDI KASUS : JL. ALAMSYAH RATU PRAWIRA NEGARA KOTA PAGAR ALAM
}

\author{
Tomi wijaya ${ }^{1)}$, Gumilar M.Sang ${ }^{2)}$, Pratnamas Dyan ${ }^{3)}$ \\ Program Studi Teknik Sipil Sekolah Tinggi Teknologi Pagaralam \\ Jalan Masig Siagim No.75 Simpang Mbacang Kec.Dempo Tengah Kota Pagar Alam \\ Sur-el : tomiwijaya@gmail.com ${ }^{1)}$
}

\begin{abstract}
Abstrak :Permasalahan transportasi adalah masalah yang selalu di hadapi oleh Negara-negara yang telah maju dan juga negara yang sedang berkembang seperti kota pagaralam, baik di bidang ekonomi maupun sosial. Perencanaan arus putaran balik (u-turn) kendaran di suatu median jaringan jalan sangat mempengaruhi keadaan lalu lintas ketika jaringan jalan memiliki suatu kinerja dengan baik, banyak keuntungan yang di dapatkan oleh masyarakat Keuntungan tersebut yang pada ahkirnya meningkatkan penghasilan dan pendapatan daerah khususnya untuk kota pagar alam jika pelayanan jalan, berjalan dengan lancar.Tujuan dari penelitian ini adalah untuk mengetahui dimensi lebar median dan penempatan u-turnpada ruas jalanAlamsyah Ratu Prawira Negara Kota pagaralam. Pengambilan data primer dilakukanselama 2 hari yaitu minggu dan senin mewakili hari kerja, yakni senin pagi pukul 06.00-18.00 WIb Survei data dilakukan meliputi perhitungan volume lalu lintas,kecepatan,kapasitas ,derajat kejenuhan,tingkat pelayanan jalan,komplik pada simpang tiga. Analisa data dilakukan dengan mentabulasidata untuk memperoleh karakteristik jalan,lebar ideal median,dan penempatan u-trunDari hasil perhitungan didapatkan volume lalu lintas jam puncak hari minggu $183 \mathrm{smp} / \mathrm{jam}$ dan senin sebesar $298 \mathrm{smp} / \mathrm{jam}$.
\end{abstract}

Kata kunci:Kapasitas jalan,dan Tingkat pelayanan jalan

Abstract :Transportation problems are problems that are always faced by developed countries and developing countries such as the city of fencealam, both in the economic and social fields. Planning a back-turn (u-turn) vehicle on a median road network greatly influences traffic conditions when the road network has a good performance, many benefits are gained by the community. The advantage is that it increases local income and income, especially for city railings. nature if road service, runs smoothly. The purpose of this study was to determine the dimensions of the median width and the placement of u-turn on the Alamsyah Ratu Prawira Negara City fencealam road segment. Primary data collection is carried out for 2 days, namely Sunday and Monday represents working days, namely Monday morning at 06.00-18.00 WIb The survey data is carried out including calculation of traffic volume, speed, capacity, degree of saturation, level of road service, complication at the intersection. Data analysis was carried out by tabulating data to obtain road characteristics, median ideal width, and total placement. From the results of calculations, the peak hour traffic volume was $183 \mathrm{smp}$ / hour and Monday was $298 \mathrm{pcu} /$ hour.

Keywork :Capacity road and level of service

\section{PENDAHULUAN 1. Latar Belakang}

Permasalahan transportasi adalah masalah yang selalu di hadapi oleh Negara-negara yang telah maju dan juga negara yang sedang berkembang seperti kota pagaralam, baik di bidang ekonomi maupun sosial. Terciptanya suatu sistem transportasi yang menjamin pergerakan manusia, kendaraan, atau barang secara lancar, aman, cepat, murah, nyaman dan sesuai dngan lingkungan sudah merupakan tujuan pembangunan dalam sektor transportasi. 
Salah satunya masalah trasnsportasi adalah putaran balik kendaran (u-turn) di median jalan, dimana suatu bagian jalan dengan kondisi kapasitas lalu lintasnya harus di kaji kinerjanya dengan banyak kendaran yang melewatinya. kondisi jalan seperti ini terjadi di jln. alamsyah ratu prawira negara, Tepatnya kota pagar alam selatan. Perencanaan arus putaran balik (u-turn) kendaran di suatu median jaringan jalan sangat mempengaruhi keadaan lalu lintas ketika jaringan jalan memiliki suatu kinerja dengan baik, banyak keuntungan yang di dapatkan oleh masyarakat Keuntungan tersebut yang pada ahkirnya meningkatkan penghasilan.

\section{Rumusan Masalah}

Berdasarkan data yang di jelaskan sebelumnya dapat di tarik rumusan masalah sebagai berikut :

1. Bagaimana karakteristik arus lalu lintas di jl. Alamsyah Ratu Prawira Negara.

2. Berapa lebar ideal median jalan dan jenis putaran balik ( $u$-turn) di jln. Alamsyah Ratu Prawira Negara.

3. Dimana lokasi yang ideal untuk menempatkan area putaran balik (u-turn) di jl. Alamsyah Ratu Prawira Negara.

\section{Ruang Lingkup Penelitian}

Penelitian yang dibahas dalam penulisan skripsi ini dibatasi pada :

1. Ruang lingkup lokasi ini di batasi pada satu lokasi studi yakni pada ruas di jln. Alamsyah Ratu Prawira Negara Kota Pagar Alam, Sumatera Selatan Sta 0+00 $\mathrm{s} / \mathrm{d}$ sta $0+600 \mathrm{~m}$ dan tidak memperhitungkan zona peralihan kendaran

2. Analisis hanya di lakukan pada aspek perencanaan (u-turn) di Jalan Alamsyah Ratu Prawira Negara Kota Pagar Alam Selatan

3. Data yang diambil berupa panjang jalan, lokasi perputaran rencana akibat adanya median rencana, lebar jalan, dan menghitung beban jalan berupa kendaran yang lewat pada ruas Jalan Alamsyah Ratu Prawira Negara.

4. Analisis dilakukan dengan tidak memperhitungkan pertumbuhan

\section{Tujuan}

1. Untuk mengetahui karakteristik arus lalu lintas di jln. Alamsyah Ratu Prawira Negara.

2. Untuk mengetahui lebar ideal median jalan dan jenis putaran balik (u-turn) di jln. Alamsyah Ratu Prawira Negara.

3. Untuk mengetahui lokasi ideal penempatan putaran balik (u-turn) di jln. Alamsyah Ratu Prawira Negara kota pagaralam.

\section{Manfaat}

Adapun manfaat dari penelitian ini adalah sebagai berikut :

\section{Bagi Penulis}

Penelitian yang dilakaukan di jalan alamsya ratu prawira negara. saya dapat mengetahui lokasi (u-turn) pengaruh dan kinerja putaran balik (u-trun) jalan terhadap karakteristik lalu lintas dan menambah wawasan penulis tentang kinerja jalan khususnya di bidang struktur jalan transportasi yang terkait.

\section{Bagi Instansi}

Dapat memberikan masukan ide yang bermanfat bagi instansi yang terkait dalam perencanan,pelaksanan, khususnya tentang ( $u$ turn) jalan sehingga dalam penerapanya dapat diketahui apa saja yang diperlukan

\section{Bagi peneliti lain}

Dari hasil penelitian ini dapat memberikan manfaat bagi pembaca. Yang berupa informasi tentang pengaruh adanya (u-turn) di jalan alamsya ratu prawira negara terhadap kinerja jalan manfaat (u-turn). dari hasil penelitian tersebut juga dapat diketahui permasalahan yang suda ada dan mencari alternatif dari permasalahan yang di hadapi.

\section{LANDASAN TEORI \\ 1. Volume Lalu Lintas}

Volume lalu lintas adalah jumlah kendaraan yang melintas satu titik pengamatan dalam satuan waktu (hari, jam, menit. Untuk merubah volume lalu lintas kend/jam dirubah menjadi smp/jam atau LHR dengan menggunakan rumus : 


\section{Kecepatan Rata-Rata Ruang}

Kecepatan didefinisikan sebagai laju dari suatu pergerakan kendaraan dihitung dalam jarak per satuan waktu (Muyasir,et all, 2014). Kecepatan yang dipilih untuk mengikat komponen perencanaan geometrik jalan dinyatakan dalam kilometer per jam $(\mathrm{km} / \mathrm{jam})$. Space mean speed (SMS) adalah kecepatan di jalan yang didasarkan atas rata-rata waktu dari semua kendaraan yang menempuh suatu jarak tertentu.

\section{Kepadatan}

Kepadatan adalah jumlah kendaraan yang menepati suatu panjang jalan atau lajur, secarah umum diekspresikan dalam kendaraan per kilometer (Muyasir, et all,2014).

\section{Hambatan Samping}

Hambatan samping adalah dampak terhadap kinerja lalu lintas dari aktivitas segmen jalan. Perhitungan hambatan samping diperlukan data geometrik dan data arus lalu lintas untuk kereb dan median (Zulfianilsih \& Jusi, 2016)

Tabel 1. Kelas Hambatan Samping

\begin{tabular}{|c|c|c|}
\hline $\begin{array}{l}\text { Kelas Hambatan } \\
\text { smping (SFC) }\end{array}$ & Kode & Kondisi khas \\
\hline Sangat rendah & VL & $\begin{array}{c}\text { Daerah permukiman ; jalan } \\
\text { dengan jalan samping }\end{array}$ \\
\hline Rendah & $\mathrm{L}$ & $\begin{array}{c}\text { Daerah permukiman ; } \\
\text { beberapa kendaraan umum }\end{array}$ \\
\hline Sedang & M & $\begin{array}{l}\text { Daerah idustri ; beberapa } \\
\text { toko disisi jalan }\end{array}$ \\
\hline Tinggi & $\mathrm{H}$ & $\begin{array}{c}\text { Daerah komersial, aktivitas } \\
\text { sisi jalan tinggi }\end{array}$ \\
\hline Sangat tinggi & $\mathrm{VH}$ & $\begin{array}{c}\text { Daerah komersial dengan } \\
\text { aktivitas pasar di samping } \\
\text { jalan }\end{array}$ \\
\hline
\end{tabular}

Sumber : MKJI(1997)

\section{Kapasitas Jalan}

Nilai kapasitas dihasilkan dari pengumpulan data lalu lintas dimana data diambil langsung survei kelapangan dan data geometrik jalan dinyatakan dalam satuan mobil penumpang (smp). Untuk jalan dua lajur - dua arah nilai kapsitasnya berdasarkan arus lalu lintas total, sedangkan jalan berlajur banyak nilai kapasitasnya di hitung per lajur.

\section{Derajat Kejenuhan}

Derajat kejenuhan (DS) berdasarkan (MKJI, 1997) adalah perbandingan antara volume lalu lintas rata-rata harian / LHR dengan kapasits jalan.

\section{Tingkat Pelayanan /Kinerja Jalan}

Berikut Ini tabel tingkat pelayanan jalan.

Tabel 2. Tipe dan deskripsi tingkat pelayanan jalan

\begin{tabular}{|c|c|c|}
\hline Tingkat pelayanann & Deskripsi kondisi jalan & $\begin{array}{c}\text { Interval rasio } \\
(\mathrm{Q} / \mathrm{C})\end{array}$ \\
\hline $\begin{array}{c}\mathrm{A} \\
\text { (free flow / arus } \\
\text { bebas) }\end{array}$ & $\begin{array}{lr}\text { Kondisi arus lalu bebas } \\
\text { dengan } & \text { kecepatan } \\
\text { tinggi, } & \text { pengemudi } \\
\text { dapat } & \text { memilih } \\
\text { kecepatan } & \text { yang } \\
\text { diinginkan } & \text { tanpa } \\
\text { hambatan } & \text { sesuai } \\
\text { dengan } & \text { batas } \\
\text { kecepatan } & \text { yang } \\
\text { ditentukan } & \end{array}$ & $0,00-0,19$ \\
\hline $\begin{array}{c}\mathrm{B} \\
\text { ( stable flow / arus } \\
\text { stabil) }\end{array}$ & $\begin{array}{l}\text { Arus lalu lintas stabil } \\
\text { kecepatan operasional } \\
\text { mulaidibatasi oleh } \\
\text { kondisi lalu lintas, } \\
\text { pengemudi memiliki } \\
\text { kebebasan yang cukup }\end{array}$ & $0,20-0,44$ \\
\hline $\begin{array}{c}\text { Tipe } \mathrm{C} \\
\text { (stable flow / arus } \\
\text { stabil) }\end{array}$ & $\begin{array}{l}\text { Arus untuk memilih } \\
\text { kecepatan masih dalam } \\
\text { batas stabil tetapi } \\
\text { kecepatan dan gerak } \\
\text { kendaraan dikendalikan } \\
\text { dibatasi dalam memilih } \\
\text { kecepatan }\end{array}$ & $0,45-0,74$ \\
\hline $\begin{array}{c}\mathrm{D} \\
\text { (approching } \\
\text { unstable flow / arus } \\
\text { hampir tidak stabil) }\end{array}$ & $\begin{array}{l}\text { Arus mendekati tidak } \\
\text { stabil, kecepatan masih } \\
\text { dikendalikan namun } \\
\text { menurun relativ cepat } \\
\text { akibat hambatan yang } \\
\text { tibul, } \\
\text { dibatasi pengemudi } \\
\text { kecepatan memilih } \\
\text { kebebasan ran } \\
\text { relativ kecil. }\end{array}$ & $0,75-0,84$ \\
\hline $\begin{array}{c}\mathrm{E} \\
\text { (untable flow / } \\
\text { arus tidak stabil) }\end{array}$ & $\begin{array}{l}\text { Arus tidak stabil karena } \\
\text { volume lalu lintas } \\
\text { mendekati berada pada } \\
\text { kapasitas dimana } \\
\text { kecepatan lebih rendah } \\
\text { dari } 40 \mathrm{~km} / \mathrm{jam} \text { dan } \\
\text { pergerakan kendaraan } \\
\text { terkadang terhenti. } \\
\text { Arus vang dipaksakan }\end{array}$ & $0,85-0,99$ \\
\hline $\begin{array}{c}\mathrm{F} \\
\text { (froced flow / arus } \\
\text { yang dipaksakan) }\end{array}$ & $\begin{array}{l}\text { atau macet } \geq 1,00 \\
\text { kecepatan rendah, } \\
\text { volume diatas kapasitas, } \\
\text { arus lalu lintas sering } \\
\text { terhenti sehingga terjadi } \\
\text { antrian panjang dan } \\
\text { hambatan-hambatan } \\
\text { yang besar. }\end{array}$ & $\geq 1,00$ \\
\hline
\end{tabular}

Sumber : MKJI (1997) 


\section{METODELOGI PENELITIAN}

\section{Lokasi Penelitian}

Penelitian ini berlokasi di Jln.Mayjen Harun Sohar kelurahan Ulu Rurah Kecamatan Pagar Alam Selatan Provensi Sumatera Selatan, dengan titik koordinat pengambilan data garis lintang $4^{\circ} \quad 1^{\prime} 35.45^{\prime \prime} \mathrm{S}$ dan garis bujur103¹5'24.73"T

Gambar 1. Lokasi penelitian
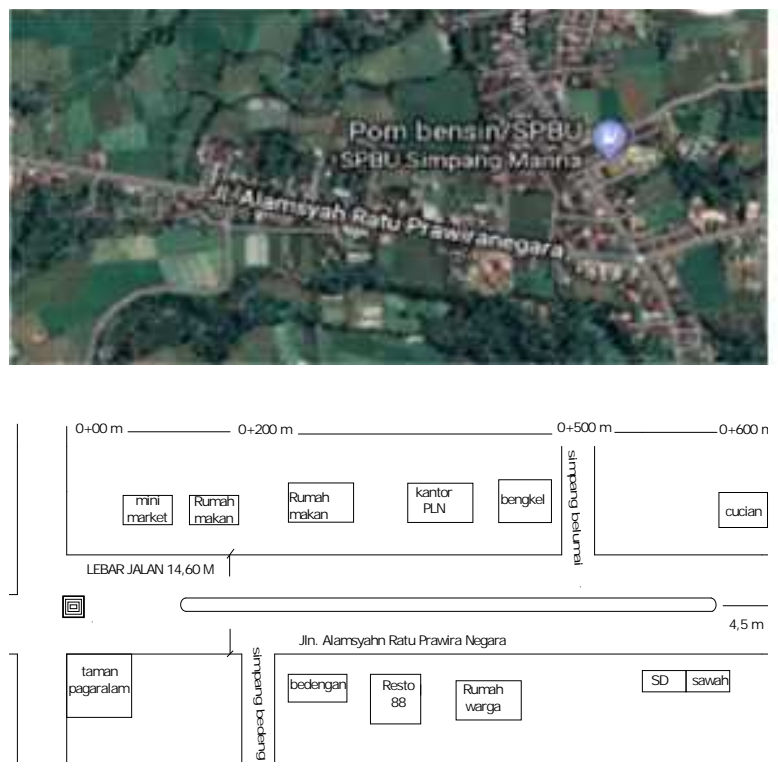

\section{Pengumpulan Data}

Pengumpulan data dalam penelitian ini dengan menggunakan data primer dan data sekunder.

\section{A. Data Primer}

Adapun data primer yang diperlukan dalam penelitian ini adalah sebagai berikut :

1. Kondisi existing geometrik jalan

2. Volume Arus lalu lintas

3. Kecepatan lalu lintas

4. Jenis kendaraan

\section{B. Data Sekunder}

Adapun data sekunder yang diperlukan dalam penelitian ini adalah sebagai berikut :

1. Jumlah penduduk kota Pagar Alam

2. Peta lokasi

\section{Metode dan Pengolahan Data}

\section{A. Data Geometrik Jalan}

Data geometrik jalan diambil langsung pengukuran ditempat lokasi penelitian data yang diambil adalah kondisi existing jalan yang berupa, lebar jalur lalu lintas efektif, lebar lajur kendaraan, tipe jalan, lebar bahu, lebar drainase dan kedalaman drainase.

\section{B. DataTipe Kendaraan}

Data tipe kendaraan dapat di bedakan dengan survei langsung arus lalu lintas di ruas jalan yang akan di survei / diamati, dari survei tersebut maka kita tahu jenis tipe kendaraan apa saja yang melewati ruas jalan tersebut. Menurut MKJI 1997 penggolongan tipe kendaraan dibedakan menejadi 4 tipe :
1. Kendaraan ringan
2. Kendaraan berat
3. Sepeda motor
4. Kendaraan tidak bermotor

\section{Data LHR (Lalu Lintas Harian Rata- Rata)}

Data LHR di dapat dari data survei atau pengamatan lansung di lapangan lalu diketahui jumlah kendraan per 15 menitan dan rata-rata persatu harinya. Kemudian hasil pengamatan selama 1 hari di jumlahkan berdasarkan arah dan jenis kendaraan.

$\mathrm{Q}=\mathrm{Q}$ kend $\mathrm{x}$ Fsmp

Dimana (kend/jam).

$\mathrm{Q}$ kend $=$ volume kendaraan

Fsmp = faktor untuk mengubah kend/jam menjadi smp/jam.

Emp didefinisikan faktor yang menunjukkan berbagai tipe kendaraan. Untuk mobil penumpang dan kendaraan ringan, Emp nya $=1,0$

Tabel 3.Daftar Besarnya Ekivalen Mobil Penumpang

\begin{tabular}{|c|c|c|c|c|}
\hline \multirow{4}{*}{$\begin{array}{l}\text { Tipe } \\
\text { jalan }\end{array}$} & \multirow{4}{*}{$\begin{array}{l}\text { Arus lalu } \\
\text { lintas total } \\
\text { dua arah } \\
\text { (kend/jam) }\end{array}$} & \multicolumn{3}{|c|}{ Emp } \\
\hline & & \multirow{3}{*}{$\begin{array}{l}\text { Kendaraan } \\
\text { berat }(\mathrm{HV})\end{array}$} & \multicolumn{2}{|c|}{$\begin{array}{c}\text { Sepeda motor } \\
(\mathrm{MC})\end{array}$} \\
\hline & & & \multicolumn{2}{|c|}{$\begin{array}{c}\text { Lebar jalur, Wc } \\
(\mathrm{m})\end{array}$} \\
\hline & & & $<6$ & $>6$ \\
\hline \multirow{2}{*}{$\begin{array}{c}\text { Dua } \\
\text { lajur tak } \\
\text { terbagi }\end{array}$} & 0 s.d 1.800 & 1,3 & 0,5 & 0,4 \\
\hline & $>1.800$ & 1,2 & 0,35 & 0,25 \\
\hline \multirow{2}{*}{$\begin{array}{l}\text { lajur tak } \\
\text { terbagi }\end{array}$} & 0 s.d 3.700 & 1,3 & \multicolumn{2}{|c|}{0.4} \\
\hline & $>3.700$ & 1,2 & \multicolumn{2}{|c|}{0,25} \\
\hline
\end{tabular}

Sumber : MKJI (1997) 


\section{Data Kecepatan Rata-Rata Ruang Lalu Lintas}

Data kecepatan rata-rata ruang arus lalu lintas didapat dari pengamatan atau survei langsung dilapangan. Data kecepatan arus diambil saat survei lalu lintas, kecepatan arus rata-rata ruang dapat dihitung dengan persamaan berikut ini :

$$
\begin{aligned}
\text { Us }=3,6 & \frac{\mathrm{x}}{\frac{\mathrm{a}}{\mathrm{a}} \cdot \sum \mathrm{t}} \ldots \ldots \ldots \ldots \ldots \ldots \ldots \ldots \ldots \ldots \ldots \ldots \ldots \\
\text { Dimana } & : \\
\mathrm{Us} & =\text { kecepatan rata-rata ruang }(\mathrm{km} / \mathrm{jam}) \\
\mathrm{x} & =\text { jarak }(\mathrm{km}) \\
\mathrm{n} & =\text { jumlah data } \\
\mathrm{t} & =\text { waktu (detik) }
\end{aligned}
$$

\section{E. Data Kepadatan Arus Lalu Lintas}

Kepadatan dapat dihitung dengan persamaan di bawah ini :

$$
\mathrm{D}=\frac{\mathrm{V}}{\mathrm{Us}}
$$

Dimana:

$$
\begin{aligned}
& \quad \mathrm{D}=\text { Kepadatan } \\
& \mathrm{V}=\text { Volume } \\
& \mathrm{U}_{\mathrm{S}}=\text { Space mean speed }
\end{aligned}
$$

\section{F. Data Kapasitas Jalan}

Adapun data yang diperlukan untuk menghitung kapasitas jalan adalah :

1.Geometrik jalan

Data geometrik jalan diperlukan untuk mengetahui tipe jalan, lebar lajur dan lebar bahu jalan, Kapasitas dasar /CO (smp/jam), nilai CO dapat dilihat pada tabel 2.17

2.Faktor penyesuaian lebar jalur jalan / Fcw, nilai Fcw berdasarkan lebar jalur jalan yang diamati

3.Faktor penyesuaian pemisah arah / FCsp, nilai FCspdapat dilhat berdasarkan keadaan jalanyang diamati.

4.Faktor penyesuaian hambatan samping / FCsf, nilaiFCsf dapat dilihat berdasarkanhambatan samping jalan yang diamati

5.Faktor penyesuaian ukuran kota / FCsc, dapat dilihatberdasarkan jumlah penduduk kotajalan yang diamati.
Kapasitas jalan dapat dihitung dengan persamaan berikut ini :

$\mathrm{C}=\mathrm{Co} \times \mathrm{FCw} \times \mathrm{FCsp} \times$ FCsf $\times$ FCcs

Dimana :

$$
\begin{aligned}
& \mathrm{C}=\text { Kapasitas }(\mathrm{smp} / \mathrm{jam}) \\
& \mathrm{CO}=\text { Kapasitas dasar }(\mathrm{smp} / \mathrm{jam}) \\
& \mathrm{Fcw}=\text { Faktor penyesuaian lebar jalur jalan } \\
& \mathrm{FCs}=\text { Faktor penyesuaian pemisah arah } \\
& \text { FCsf }=\text { Faktor penyesuaian hambatan samping } \\
& \text { FCcs }=\text { Faktor penyesuaian ukuran kota }
\end{aligned}
$$

Adapun nilai variabel-variabel yang termasuk dalam kapasitas, antara lain :

\begin{tabular}{|c|c|c|}
\hline Tipe Jalan & Lebar Efektif Jalan & $\mathrm{FCw}$ \\
\hline \multirow{6}{*}{$\begin{array}{c}\text { Empat - lajur } \\
\text { Terbagi } \\
\text { Enam - lajur Terbagi }\end{array}$} & Per lajur & \\
\hline & 3,00 & 0,92 \\
\hline & 3,25 & 0,96 \\
\hline & 3,50 & 1,00 \\
\hline & 3,75 & 1,04 \\
\hline & 4.00 & 1,08 \\
\hline \multirow{6}{*}{$\begin{array}{c}\text { Empat - lajur tak } \\
\text { terbagi }\end{array}$} & Per lajur & \\
\hline & 3,00 & 0,91 \\
\hline & 3,25 & 0,95 \\
\hline & 3,50 & 1,00 \\
\hline & 3,75 & 1,05 \\
\hline & 4,00 & 1,09 \\
\hline
\end{tabular}

1. Faktor kapasitas dasar (CO) ditunjukan dalam tabel berikut ini :

Tabel 2.17. Kapasitas Dasar Jalan Antar Kota

\begin{tabular}{|c|c|c|}
\hline Tipe Jalan & $\begin{array}{c}\text { Kapasitas Dasar } \\
(\text { Smp/Jam })\end{array}$ & Keterangan \\
\hline 4 lajur terbagi & 1650 & Perlajur \\
4 lajur tak terbagi & 1500 & Per lajur \\
2 lajur tak terbagi & 2900 & Total 2 arah \\
\hline \multicolumn{2}{|l}{ Sumber : MKJI (1997) }
\end{tabular}

2. Faktor penyesuaian kapasitas jalan akibat pemisah arah (FCsp) terlihat pada tabel berikut ini :

Tabel 2.19. Penyesuaian Kapasitas Akibat Pemisah Arah

\begin{tabular}{cccccc}
\hline $\begin{array}{c}\text { Pemisah arah SP \% } \\
-\%\end{array}$ & $\begin{array}{c}50- \\
50\end{array}$ & $\begin{array}{c}55- \\
45\end{array}$ & $\begin{array}{c}60- \\
40\end{array}$ & $\begin{array}{c}65- \\
35\end{array}$ & $30-$ \\
\hline Dua - lajur (2/2) & 1,00 & 0,97 & 0,94 & 0,91 & 0,88 \\
Empat - lajur (4/2) & 1,00 & 0,985 & 0,97 & 0,955 & 0,94 \\
\hline Sumber : MKJI (1997) & & & & &
\end{tabular}

3. Faktor penyesuian kapasitas akibat lebar jalur lalu lintas $(\mathrm{FCw})$ ditunjukan pada tabel berikut ini :

Tabel 2.18. Penyesuaian Kapasitas Akibat

Pengaruh Lebar Jalur Lalu Lintas 


\begin{tabular}{ccc}
\hline & Total kedua arah & \\
& 5 & 0,56 \\
Dua - lajur Tak & 6 & 0,87 \\
terbagi & 7 & 1,00 \\
& 8 & 1,14 \\
& 9 & 1,25 \\
& 10 & 1,29 \\
& 11 & 1,34 \\
Sumber: $M K J I(1997)$ & 14 & 1,00
\end{tabular}

G. Data Derajat Kejenuhan

Derajat kejenuhan dapat dihitung dengan persamaan berikut ini :

$\mathrm{DS}=\frac{\mathrm{Q}}{\mathrm{C}}$

Dimana :

$\mathrm{Q}=$ Arus total $(\mathrm{smp} / \mathrm{jam})$

C $=$ Kapasitas (smp/jam)

4. Faktor penyesuaian kapasitas akibat hambatan samping (FCsf) dapat dilihat pada tabel berikut ini :

Tabel 2.20. Faktor Penyesuaian Kapasitas Akibat Hambatan Samping

\begin{tabular}{|c|c|c|c|c|c|}
\hline \multirow{3}{*}{$\begin{array}{l}\text { Tipe } \\
\text { Jalan }\end{array}$} & \multirow{3}{*}{$\begin{array}{c}\text { Kelas } \\
\text { Hambatan } \\
\text { Samping }\end{array}$} & \multicolumn{4}{|c|}{$\begin{array}{l}\text { Faktor Penyesuaian Akibat } \\
\text { hambatan Samping (FCsf) }\end{array}$} \\
\hline & & \multicolumn{4}{|c|}{ Lebar Bahu Efektif } \\
\hline & & $\leq 0,5$ & 1,0 & 1,5 & $\geq 2$ \\
\hline \multirow{6}{*}{$4 / 2 \mathrm{D}$} & VL & 0,96 & 0.98 & 1,01 & 1,03 \\
\hline & $\mathrm{L}$ & 0,94 & 0,97 & 1,00 & 1,02 \\
\hline & M & 0,92 & 0,95 & 0,98 & 1,00 \\
\hline & $\mathrm{H}$ & 0,88 & 0,92 & 0,95 & 0,98 \\
\hline & VH & 0,84 & 0,88 & 0,92 & 0,96 \\
\hline & VL & 0,96 & 0.98 & 1,01 & 1,03 \\
\hline \multirow{6}{*}{$4 / 2 \mathrm{UD}$} & VL & 0,96 & 0,99 & 1,01 & 1,03 \\
\hline & $\mathrm{L}$ & 0,94 & 0,97 & 1,00 & 1,02 \\
\hline & M & 0,92 & 0,95 & 0,98 & 1,00 \\
\hline & $\mathrm{H}$ & 0,84 & 0,91 & 0,94 & 0,98 \\
\hline & VH & 0,80 & 0,86 & 0,90 & 0,95 \\
\hline & VL & 0,96 & 0,99 & 1,01 & 1,03 \\
\hline \multirow{6}{*}{$2 / 2 \mathrm{UD}$} & VL & 0,94 & 0,96 & 0,99 & 1,01 \\
\hline & $\mathrm{L}$ & 0,92 & 0,94 & 0,97 & 1,00 \\
\hline & M & 0,89 & 0,92 & 0,95 & 0,98 \\
\hline & $\mathrm{H}$ & 0,82 & 0,86 & 0,90 & 0,95 \\
\hline & $\mathrm{VH}$ & 0,73 & 0,79 & 0,85 & 0,91 \\
\hline & VL & 0,94 & 0,96 & 0,99 & 1,01 \\
\hline
\end{tabular}

Sumber : MKJI (1997)

5. Faktor penyesuaian kota (FFVcs)

Tabel 2.22. Faktor Penyesuaian Untuk Pengaruh

Ukuran Kota pada Kecepatan Arus Bebas

Kendaraan Ringan (FFVcs), Jalan Perkotaan

Ukuran kota (juta Faktor penyesuaian untuk penduduk) ukuran kota

$\begin{array}{cc}<0,1 & 0,90 \\ 0,1-0,5 & 0,93 \\ 0,5-1,0 & 0,95 \\ 1,0-3,0 & 1,00 \\ >3,0 & 1,03\end{array}$

Sumber : MKJI 1997

0,90

0,93

1,00

1,03

\section{F.Diagram Alir Penelitian}

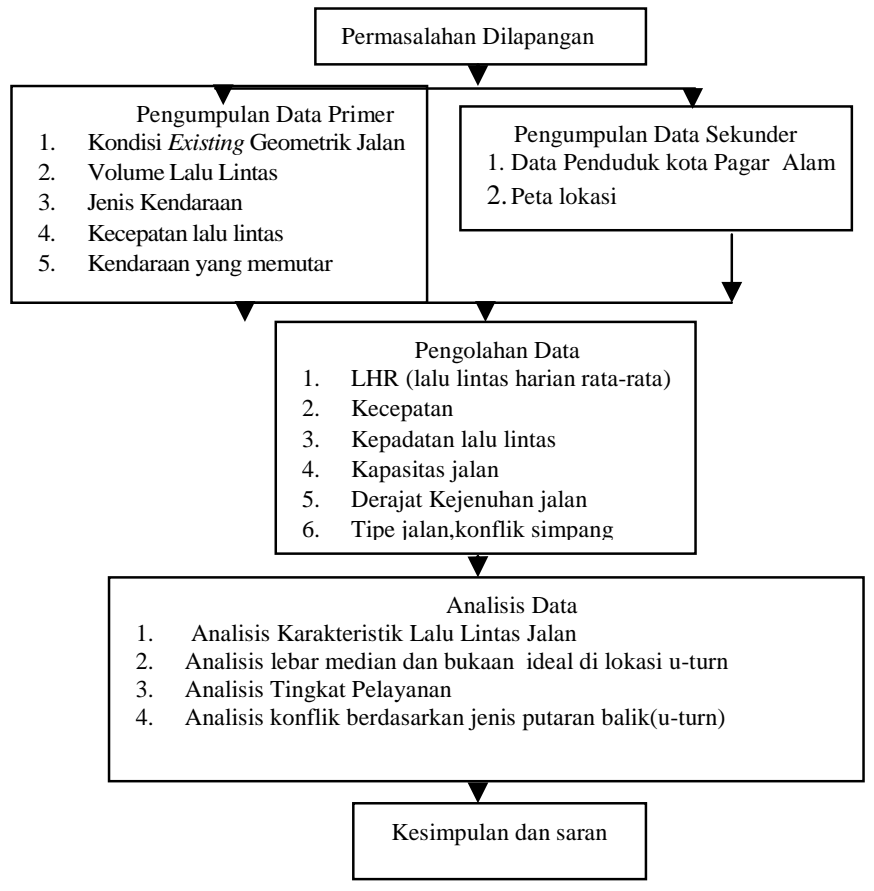

\section{ANALISIS DAN PEMBAHASAN}

\section{Data Geometrik Jalan}

Berdasarkan hasil dari pengamatan di segmen jalan Alamsyah Ratu Prawira Negara kota Pagar Alam didapat panjang jalan 600 meter, lebar efektif jalur lalu lintas adalah 14,60 meter, dengan lebar bahu jalan 2 meter tanpa perkerasan yang memiliki lebarm drainase 1.5 meter dengan kedalaman drainase 0.6 meter. Panjang penelitian saya adalah $0+00$ meter yang mana dimulai dari sta $0+600$ dimana panjang jalan tersebut sudah memiliki lebar jalur lalu lintas yang sama

\section{Data Volume Lalu Lintas}

Survei volume lalu lintas dilaksanakan selama (dua) hari yaitu minggu 01 april 2018 dan senin 02 april 2018. Selama 12 jam pelaksanaan survei yaitu dimulai dari pukul 06.00 WIB sampai pukul 18.00 WIB ruas jalan Mayjen Harun Sohar kota Pagar Alam. 
Data hasil survey dapat dilihat pada tabel berikut ini :

Tabel 9.Data volume lalu lintas jam puncak total kedua arah penelitian (dari arah sp.manak ka arah pasar dan dari arah pasar ke arah sp.manak)

\begin{tabular}{|c|c|c|c|c|}
\hline \multicolumn{2}{|c|}{ Waktu Penelitian } & \multirow{2}{*}{$\begin{array}{c}\text { Sepeda } \\
\text { Motor } \\
\text { Hari }\end{array}$} & $\begin{array}{c}\text { Kendaraan } \\
\text { Ringan } \\
\text { (Kend/Jam) }\end{array}$ & $\begin{array}{c}\text { Kendaraan } \\
\text { Berat } \\
\text { (Kend/Jam) }\end{array}$ \\
\hline minggu & $13.00-14.00$ & 1697 & 449 & 13 \\
\hline Senin & $17.00-18.00$ & 1659 & 379 & 21 \\
\hline \multicolumn{2}{|c|}{ Sumber : Hasil Analisis Data, 2018 } \\
\hline
\end{tabular}

\section{Data Kecepatan Lalu Lintas}

Pengambilan data kecepatan dilaksanakan selama 2 hari bersamaan dengan pengambilan data volume lalu lintas berikut ini hasil dari survei kecepatan :

Data waktu tempuh kendaraan jam puncak total kedua arah penelitian (dari simpang manak ke pagar agung dan pagar agung ke simpang mannak)

\begin{tabular}{|c|c|c|}
\hline \multicolumn{2}{|c|}{ Waktu Penelitian } & \multirow{2}{*}{$\begin{array}{c}\text { Waktu tempuh kendaraan } \\
\text { Ringan (Detik) }\end{array}$} \\
\hline Hari & Jam & \\
\hline minggu & $15.00-16.00$ & 14,28 \\
\hline Senin & $11.00-12.00$ & 12,50 \\
\hline
\end{tabular}

\section{Data Jumlah Penduduk Kota Pagar Alam}

Jumlah penduduk kota Pagar Alam di dapat dari kantor badan statistik kota Pagar Alam. Berdasarkan data dari badan pusat statik, penduduk kota Pagar alam tahun 2017 berjumlah 135.328 jiwa dengan rincian 69.304 laki - laki dan 66.304 perempuan.

\section{A. ANALISIS LHR}

Analisis ini adalah mengubah data volume lalu lintas dari kend/jam ke smp/jam, dengan cara mengalikan volume lalu lintas baik sepeda motor, kendaraan ringan dan kendaraan berat dengan nilai emp (ekivalen mobil penumpang), nilai emp dapat dilihat pada tabel 2.7. Data yang digunakan adalah data rekapitulasi dari kedua arah kendraan setiap pengamatan.

Volume lalu lintas jam puncak total kedua arah penelitian kend/jam menjadi smp/jam

(dari simpang manak ke pagar agung dan pagar agung ke simpang mannak)

\begin{tabular}{|c|c|c|c|c|c|}
\hline \multicolumn{2}{|c|}{ Waktu Penelitian } & \multirow[b]{2}{*}{$\begin{array}{c}\text { SepedaMotor } \\
\text { smp/ Jam }\end{array}$} & \multirow{2}{*}{$\begin{array}{c}\text { Kend } \\
\text { Ringan } \\
\text { smp/ } \\
\text { Jam }\end{array}$} & \multirow{2}{*}{$\begin{array}{l}\text { Kend } \\
\text { Berat } \\
\text { smp/ } \\
\text { Jam }\end{array}$} & \multirow{2}{*}{$\begin{array}{c}\text { Volume } \\
\text { Total } \\
\text { Kendaraan } \\
\text { smp/jam) }\end{array}$} \\
\hline Hari & Jam & & & & \\
\hline
\end{tabular}

\begin{tabular}{|c|c|c|c|c|c|}
\hline minggu & $\begin{array}{c}14.00- \\
15.00\end{array}$ & 2412 & 244 & 19,5 & 504,7 \\
\hline \multirow{2}{*}{ senin } & $\begin{array}{c}07.00- \\
08.00\end{array}$ & 4852 & 20,3 & 3,9 & 509,4 \\
\hline
\end{tabular}

Sumber : Hasil Analisis Data, 2018

\section{B. Analisis Kecepatan}

Hasil perhitungan kecepatan selama 2 hari pengamatan Pada hari minggu 01 april 2018 dan senin 02 april 2018. Data yang digunakan adalah data rekapitulasi dari kedua arah kendaraan setiap pengamatan.

Hasil Perhitungan kecepatan dari satuan meter/detik menjadi $\mathrm{Km} / \mathrm{Jam}$ (dari simpang manak ke pagar agung dan pagar agung ke simpang manak )

\begin{tabular}{|c|c|c|c|}
\hline \multicolumn{2}{|c|}{ Waktu Penelitian } & \multirow{2}{*}{$\begin{array}{c}\text { Waktu } \\
\text { tempuh } \\
\text { kendaraan } \\
\text { (detik) }\end{array}$} & \multirow{2}{*}{$\begin{array}{c}\text { Kendaraan } \\
\text { Ringan } \\
(\mathrm{Km} / \mathrm{Jam})\end{array}$} \\
\hline Hari & Jam & & \\
\hline minggu & $15.00-16.00$ & 14,28 & 51,39 \\
\hline Senin & $11.00-12.00$ & 12,50 & 45,00 \\
\hline
\end{tabular}

\section{Analisis Kepadatan Lalu Lintas}

Kepadatan lalu lintas dapat dihitung dengan cara membagi volume arus dengan kecepatan rata ruang.

Hasil perhitungan kepadatan total kedua arah penelitian (dari simpang manak ke pagar agung dan pagar agung ke simpang mannak)

\begin{tabular}{|c|c|c|c|}
\hline $\begin{array}{c}\text { waktu } \\
\text { penelitian }\end{array}$ & $\begin{array}{c}\text { Volume total } \\
\text { smp/jam }\end{array}$ & $\begin{array}{c}\text { kecepatan } \\
\text { kendaraan } \\
\text { km/jam }\end{array}$ & $\begin{array}{c}\text { Kepadatan } \\
\text { kendaraan smp/kn }\end{array}$ \\
\hline $16.00-17.00$ & 520,6 & 39,85 & 560,45 \\
\hline $07.00-08.00$ & 509,4 & 29,2 & 538,6 \\
\hline
\end{tabular}

Sumber : Hasil Analisis Data, 2018

\section{Analisis Kapasitas Jalan}

Untuk perhitungan kapasitas jalan adalah dengan menentukan nilai -nilai yang akan dijadikan dasar dalam perhitungan yaitu nilai kapasitas dasar dan beberapa nilai faktor penyesuaian.

\section{Perhitungan Kapasitas Jalan Bertipe 4/2 UD} Gambar4. 1 tipe 4/2 UD perlajur 3,65 m

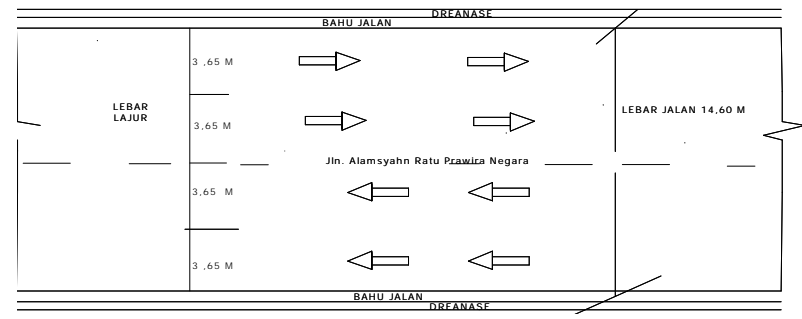

Sumber :Jalan bertipe 4/2 UD, 2018 
Dengan :

1. CO adalah kapasitas dasar .4/2 UD (empat lajur dua arah tanpa pembatas median) Nilai co dapat dilihat pada tabel 2.17.1500 smp/jam untuk pelajur

2. Fcw adalah faktor penyesuaian lebar jalur untuk jalan 4/2UD bisa dilihat pada tabel 2.18 yang mana 4 lajur tanpa pembatas median perlajur 3,65 berdasarkan hasil interpolasi 3,5 dengan 3,75 dengan nilai faktor penyesuaiyan lebar lajur 1,00 dengan 1,05 di dapatkan nilai interpolasi yaitu 1,03

3. FCsp yaitu faktor penyesuaian kapasitas jalan akibat pemisah arah yang bisa dilihat pada tabel 2.19 yang mana pembagian arah $50-50 \%$ dengan tipe jalan (4/2UD) yaitu 1,0

4. FCsf yaitu faktor penyesuaian akibat hambatan samping dengan hambatan samping rendah berdasarkan tabel 2.20 adalah 1,02

5. FCcs yaitu faktor penyesuaian ukuran kota dengan jumlah penduduk 135.328 jiwa yang berati kurang dari 0,1 juta penduduk ,Bedasarkan tabel 2.22 yaitu untuk pengaruh ukuran kota FCcs adalah 0,9.

$\mathrm{C}=\mathrm{Co} \times \mathrm{FCw} \times$ FCsp $\mathrm{xFCsf} \times \mathrm{FCcs}$

$=1500 \times 4 \times 1,03 \times 1,00 \times 1,02 \times 0,90$

$=5673,24 \mathrm{smp} / \mathrm{jam}$

\section{Perhitungan Kapasitas Jalan Bertipe $4 / 2$}

UD

Gambar 3. Tipe Jalan 4/2D perlajur $3 \mathrm{~m}$

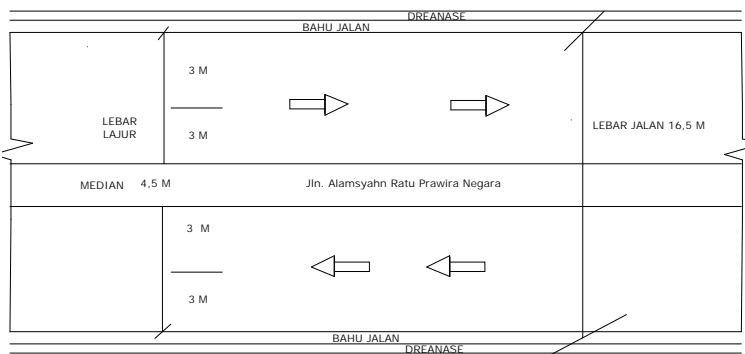

Sumber : Tipe Jalan 4/2, 2018

Dengan :

1. CO adalah kapasitas dasar .dengan jalan bertipe 4/2 D (empat lajur dua arah ber pembatas median) nilai $\mathrm{Co}$ dapat dilihat pada tabel 2.17 yaitu 1.650 untuk pelajur

2. Fcw adalah faktor penyesuaian lebar jalur untuk jalan 4/2 D perlajur $3 \mathrm{~m}$ (empat lajur dua arah ber pembatas median)dengan syarat penambahan lebar jalan 1,9 $\mathrm{m}$ bisa dilihat pada tabel 2.18 yaitu dengan nilai 0,92

3. FCsp yaitu faktor penyesuaian kapasitas jalan akibat pemisah arah dengan pemisah masing-masing 50$50 \%$ maka nilai fCsf bisa dilihat pada tabel 2.19 yaitu 1,00

4. FCsf yaitu faktor penyesuaian akibat hambatan samping , berdasarkan hasil penelitian di lapangan di jalan Alamsyah Ratu Prawira Negara Kota Pagaralam termasuk kelas hambatan samping rendah 2.20 adalah 1,02

5. FCcs yaitu faktor penyesuaian ukuran kota dengan jumlah penduduk 135.328 jiwa yang berati kurang dari 0,1 juta penduduk Bedasarkan tabel 2.22 yaitu FCcs adalah 0,90

$\mathrm{C}=\operatorname{Co} \times$ FCw $\mathrm{x}$ FCsp $\mathrm{xFCsf} \times \mathrm{FCcs}$

$=1650 \times 4 \times 0,92 \times 1,00 \times 1,02 \times 0,90$

$=5067,36 \mathrm{smp} / \mathrm{jam}$

\section{Perhitungan Kapasitas Jalan Bertipe 4/2 D}

Gambar 4 Tipe jalan 4/2 D perlajur 3,275 m

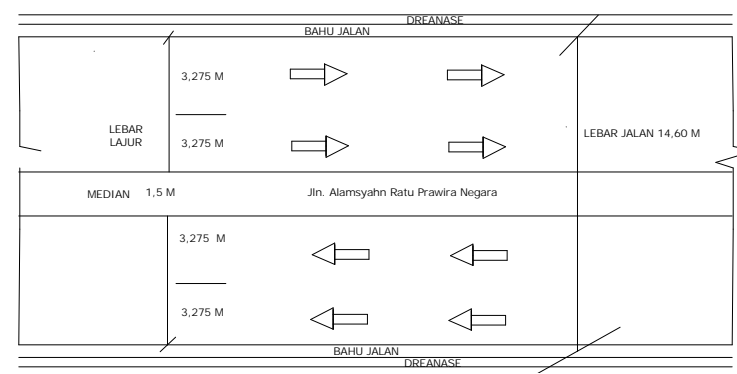

Sumber : Jalan Bertipe 4/2 D, 2018

Dengan :

1. CO adalah kapasitas dasar .dengan jalan bertipe 4/2 D (empat lajur dua arah ber pembatas median) nilai Co dapat dilihat pada tabel 2.17 yaitu 1.650 untuk pelajur

2. Fcw adalah faktor penyesuaian lebar jalur untuk jalan 4/2 D (empat lajur dua arah ber pembatas median) dengan perlajur 3,275 $\mathrm{m}$ berdasarkan hasil interpolasi antarah perlajur 3,25 dan 3,5 dan nilai faktor penyesuaian lebar lajur 0,96 dengan 1,00 sehingga didapatkan nilai interpolasi 0,964

3. FCsp yaitu faktor penyesuaian kapasitas jalan akibat pemisah arah dengan pemisah 
masing-masing 50-50 \% maka nilai fCsf bisa dilihat pada tabel 2.19 yaitu 1,00

4. FCsf yaitu faktor penyesuaian akibat hambatan samping, berdasarkan hasil penelitian di lapangan di jalan Alamsyah Ratu Prawira Negara Kota Pagaralam termasuk kelas hambatan samping rendah 2.20 adalah 1,02

5. FCcs yaitu faktor penyesuaian ukuran kota dengan jumlah penduduk 135.328 jiwa yang berati kurang dari 0,1 juta penduduk ,Bedasarkan tabel 2.22 yaitu FCcs adalah 0,90

$\mathrm{C}=\mathrm{Co} \times \mathrm{FCw} \times \mathrm{FCsp} \times \mathrm{xCsf} \times \mathrm{FCcs}$

$=1650 \times 4 \times 0,964 \times 1,00 \times 1,02 \times 0,90$

$=5840,6832 \mathrm{smp} / \mathrm{jam}$

\section{E. Analisis Derajat Kejenuhan}

Analisis derajat kejenuhan didapat dari volume lalu lintas berbanding dengan kapasitas, untuk volume diambil jam puncak tertinggi yaitu hari senin pukul $07.00-08.00$ WIB yaitu sebanyak 509,4 smp/jam.

Derajat kejenuhan Untuk tipe jalan 4/2 UD

$$
\begin{aligned}
\mathrm{DS} & =\mathrm{Q} / \mathrm{C} \\
& =509,4 \mathrm{Smp} / \mathrm{jam} 5673,24 / \mathrm{smp} / \mathrm{jam} \\
& =0,8
\end{aligned}
$$

Derajat kejenuhan Untuk tipe jalan 4/2 D

(L.perlajur 3,0 m)

$$
\begin{aligned}
\mathrm{DS} & =\mathrm{Q} / \mathrm{C} \\
& =509,4 \quad \text { Smp/jam / 5067,36 smp/ja } \\
& =0,10
\end{aligned}
$$

Derajat kejenuhan Untuk tipe jalan 4/2 D (L.perlajur 3,275 m)

$$
\begin{aligned}
\mathrm{DS} & =\mathrm{Q} / \mathrm{C} \\
& =509,4 \mathrm{Smp} / \mathrm{jam} / 5840,6832 \mathrm{smp} / \mathrm{jam} \\
& =0,8
\end{aligned}
$$

\section{F. Analisis Tingkat Peleyanan Jalan}

Berdasarkan tipe jalan dan tingkat pelayanan jalan Alamsyah Ratu prawira negara Kota Pagar Alam untuk tipe jalan 4/2 UD dengan perlajur 3,65 dengan nilai derajat kejenuhan 0,8 termasuk tingkat pelayanan jalan tingkat

\begin{tabular}{|c|c|c|c|}
\hline \multicolumn{4}{|c|}{ Tingkat } \\
\hline $\begin{array}{l}\text { Tipe } \\
\text { jalan }\end{array}$ & $\begin{array}{l}\text { Nilai DS } \\
\text { (smp/jam) }\end{array}$ & $\begin{array}{c}\text { Tingkat } \\
\text { Pelayanan } \\
\text { Jalan }\end{array}$ & Keterangan \\
\hline $4 / 2 \mathrm{UD}$ & 0,8 & A & $\begin{array}{l}\text { Kondisi arus lalu bebas dengan kecepatan } \\
\text { tinggi, pengemudi dapat memilih kecepatan } \\
\text { yang diinginkan tanpa hambatan sesuai } \\
\text { dengan batas kecepatan yang ditentukan }\end{array}$ \\
\hline $\begin{array}{c}4 / 2 \mathrm{D} \\
\text { perlajur } \\
3 \mathrm{M}\end{array}$ & 0,10 & A & $\begin{array}{l}\text { Kondisi arus lalu bebas dengan kecepatan } \\
\text { tinggi, pengemudi dapat memilih kecepatan } \\
\text { yang diinginkan tanpa hambatan sesuai } \\
\text { dengan batas kecepatan yang ditentukan }\end{array}$ \\
\hline $\begin{array}{l}4 / 2 \mathrm{D} \\
\text { perlajur } \\
3,275 \mathrm{M}\end{array}$ & 0,8 & A & $\begin{array}{l}\text { Kondisi arus lalu bebas dengan kecepatan } \\
\text { tinggi, pengemudi dapat memilih kecepatan } \\
\text { yang diinginkan tanpa hambatan sesuai } \\
\text { dengan batas kecepatan yang ditentukan }\end{array}$ \\
\hline
\end{tabular}
A, untuk tipe jalan 4/2D perlajur $3 \mathrm{~m}$ dengan nialai derajat kejenuhan 0,10 termasuk tingkat pelayanan jalan tingkat $\mathrm{A}$, sedangkan utuk tipe Jalan 4/2 D perlajur 3,275 M dengan nilai derajat kejenuhan 0,8 termasuk tingkat pelayanan jalan tingkat $\mathrm{A}$
Tabel 14. Tingkat Pelayanan Jalan Bedasarkan Derajat Kejenuhan

Sumber : Hasil Analisis Data, 2018

\section{G . Konflik di persimpangan dan Putaran Balik (u-turn)}

1. Konflik kendaraan di simpang tiga belumai untuk kondisi (eksisting) dengan tipe jalan 4/2UD.

Gambar 4. 2 konflik kendaraan di simpang tiga belumai kondisi exsisting

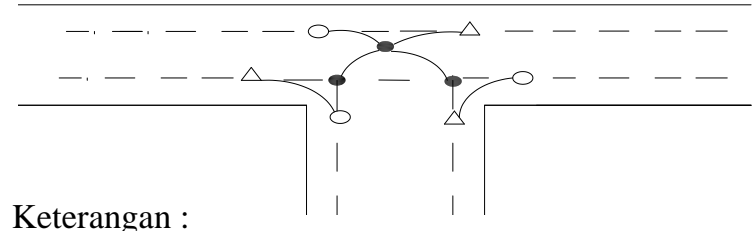

- : Titik konflik Persilangan (3 Titik)

$\Delta$ :Titik Konflik Pengabungan (3Titik)

o: Titik Konflik memisah (3Titik)

2. Titik konflik persimpangan, kebutuhan lebar median apabila gerakan puatar balik dari lajur dalam ke bahu jaln 4/2D .Yang dapat dilihat pada Gambar 4.18 berikut:

Gambar 4. 3Tipe 1 perlajur 3,275

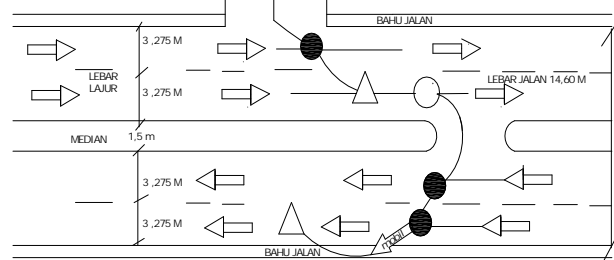

Sumber: analisis 2018

Untuk keterrangan gambar di atas dapat dijelaskan dengan urutan sebagai berikut:

- : Titik konflik Persilangan ( 3 Titik)

$\Delta$ :Titik Konflik Pengabungan (2Titik)

o: Titik Konflik memisah (1Titik) 
3. Titik konflik persimpangan pada kebutuhan lebar median apabila gerakan putar balik dari lajur dalam ke lajur ke dua jalur lawan tipe 4/2D apabila di tambah lebar jaln 1,9 m yang mana dapat dilihat pada Gambar berikut ini.. Gambar 4. 4 Tipe 2



Sumber: analisis 2018

Untuk keterangan gambar di atas dapat dijelaskan dengan urutan sebagai berikut:

•: Titik konflik Persilangan (2 Titik)

$\Delta$ :Titik Konflik Pengabungan (2Titik)

o: Titik Konflik memisah (1Titik)

\section{KESIMPULAN DAN SARAN 1. Kesimpulan}

Dari analisis di Ruas Jalan Alamsyah Ratu Prawira Negara Kota pagarAlam dalam penelitian ini, maka kesimpulan yang dapat diambil adalah sebagai berikut:

1. Berdasarkan hasil analisis karakteristik lalu lintas di dapatkan :

a. volume jam puncak hari minggu adalah 14.00 - 15.00 WIB sebanyak 504,7

smp/jam dansenin yaitu pukul 07.00 08.00 sebanayak 509,4 kendaraan smp/jam

b. Untuk keterangan kecepata puncak pada hari minggu yaitu jam 15.00-16.00 yaitu 51,39 $\mathrm{km} / \mathrm{jam}$ dan kecepatan pada hari senin yaitu jam 08.00 - 09.00 dengan rata-rata ruang . $45,00 \mathrm{~km} / \mathrm{jam}$

c. Untuk kepadatan puncak hari minggu adalah jam 16.00-17.00 yaitu 560,45 smp/km dan kepadatan puncak hari senin adalah jam 07.00-08.00 yaitu 538,6 smp/km

2 Hasil dari analisis lebar median dan jenis putaran balik (u-turn) didapatkan pada tabel berikut ini:

\begin{tabular}{|c|c|c|c|c|c|}
\hline $\begin{array}{l}\text { Tipe } \\
\text { jalan }\end{array}$ & $\begin{array}{l}\text { Lebar } \\
\text { median }\end{array}$ & $\begin{array}{l}\text { Jenis } \\
\text { putaran }\end{array}$ & $\begin{array}{l}\text { Lebar } \\
\text { perlajux }\end{array}$ & $\begin{array}{c}\text { Nilai } \\
\text { Derajat } \\
\text { jemuh } \\
\text { (smajam) }\end{array}$ & $\begin{array}{c}\text { Tingkat } \\
\text { pelayanaa }\end{array}$ \\
\hline $\begin{array}{l}\text { 4/2UD } \\
\text { (exsistin } \\
\text { g) }\end{array}$ & - & - & $3.65 \mathrm{~m}$ & 0,8 & A \\
\hline $42 D$ & $1,5 \mathrm{~m}$ & $\begin{array}{c}\text { Jalur dalam } \\
\text { ke bahu }\end{array}$ & $3,275 \mathrm{~m}$ & 0,10 & A \\
\hline $42 \mathrm{D}$ & $4,5 \mathrm{~m}$ & $\begin{array}{l}\text { Talur dalame } \\
\text { ke jalar ke } \\
\text { dua lawag }\end{array}$ & $3,0 \mathrm{~m}$ & 0.08 & A \\
\hline $2 / 2 \mathrm{D}$ & $8.5 \mathrm{mt}$ & $\begin{array}{l}\text { Jalur dalem } \\
\text { ke dalam }\end{array}$ & $3,05 \mathrm{~m}$ & \multicolumn{2}{|c|}{$\begin{array}{l}\text { Thdak ada dalant } \\
\text { pedoman MKJ } 1997 \text {. }\end{array}$} \\
\hline
\end{tabular}

3 Untuk lokasi ideal penempatan putaran balik pada Jalan Alamsyah Ratu Prawira Negara Kota Pagaralam yaitu dari sta 0+600 dengan alasan bahwa lokasi penempatan pemutaran normal jaraknya $500 \mathrm{~m}$ sedangkan $100 \mathrm{~m}$ diasumsikan sebagai lokasi peralihan untuk mengurangi konflik dipersimpangan belumai.Untuk analisis berdasarkan konflik di persimpangan tiga putaran balik dapat dilihat pada tabel berikut ini:

\begin{tabular}{|c|c|c|}
\hline Tipe falan & kroplik di (w-mimo & \\
\hline Sirugang Tha & 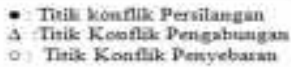 & $\begin{array}{l}\text { (9) Tras) } \\
\text { (STitik) } \\
\text { (STitik) }\end{array}$ \\
\hline 4/2D Lebar pestajur 3,275 m & $\begin{array}{l}\text { - Tinik kondik Pessiangan } \\
\text { A Titik Konflik Prianabuatuman } \\
\text { o Titik Konflik memianh }\end{array}$ & $\begin{array}{l}\text { ( } 3 \text { Driak) } \\
\text { (2Titik) } \\
\text { (1Titik) }\end{array}$ \\
\hline 420 Lebax pestajur $3 \mathrm{~m}$ & 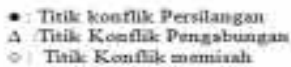 & $\begin{array}{l}\text { C) Ditio } \\
\text { (2Titik) } \\
\text { OTitik) }\end{array}$ \\
\hline
\end{tabular}

Sumber : analisis 2018

Dari tabel di atas dapat disimpulkan bahwa semakin sedikit konflik maka semakin minim terjadinya kecelakaan berdasarkan lebar perlajur jalan. Sehingga semakin efektif untuk perencanaan lebar median dan bukaan (u-turn) pada jalan Alamsyah Ratu Prawira Negara kota pagaralam.

\section{Saran}

Dari analisis di Ruas Jalan Alamsyah Ratu Prawira Negara Kota pagarAlam dalam skripsi ini, maka disarankan menggunakan .Tipe jalan 4/2D dengan perlajur $3 \mathrm{~m}$ dan lebar median jalan $4,5 \mathrm{~m}$ ini dengan tingkat pelayanan (A) dan untuk komplik lalu lintasnya paling sedikit yaitu Titik konflik Persilangan (2 Titik) ,Titik Konflik Pengabungan (2Titik), Titik Konflik memisah (1Titik) . Akan tetapi perlu adanya perkerasan dan pelebaran jalan sebesar 1,9 $\mathrm{m}$.

\section{DAFTAR PUSTAKA}

Departemen Pekerjaan Umum,1997, Manual Kapasitas Jalan Indonesia(MKJI), Direktorat Jenderal Bina Marga dan Departemen Pekerjaan Umum, Jakarta.

Binamarga/no:06/BM/20005)Pedoman Perencanaan putar balik (u-turn

Soadang, H. (2004). Konstruksi jalan raya.Bandung: Nova.

Zulfianilsih, F., \& Jusi, U. (2016). Jurnal teknik sipil siklus, vol.2, no. 1. Analisa kinerja ruas jalan berdasarkan derajat kejenuhan jalan , $1-23$.

Pedoman Direktorat Jenderal Bina Marga , Direktorat Pembinaan Jalan Kota no.014/T/BNKT/1990, Tata cara perencanaan pemisah 